\title{
Small and Medium-Sized City: The Main Battle Field of the New Urbanization Construction
}

\author{
Lv Jian ${ }^{1}$, Li Zhengang ${ }^{2}$ \\ ${ }^{1}$ Department of Social Science, North China Institute of Aerospace Engineering, Langfang, China \\ ${ }^{2}$ Party Committee Propaganda Department, North China Institute of Aerospace Engineering, Langfang, China \\ Correspondence: Lv Jian, Department of Social Science, North China Institute of Aerospace Engineering, 133 Aimin \\ Road, Guangyang District, Langfang, China
}

Received: February 9, 2015

doi:10.11114/ijsss.v3i3.776
Accepted: March 23, 2015

Available online: April 21, 2015

\begin{abstract}
Small and medium-sized cities have played important roles in China's new urbanization strategies. Small and medium-sized cities can not only help large cities avert over-concentration of population, but also avoid excessively decentralizing rural industrialization in small towns. To develop small and medium-sized cities, characteristic industries and vocational education are required so that people can get employed in the cities and become residents easily. City infrastructure and public services are necessary for urban residents. Public-Private Partnership may solve the problems of fund shortage that the local government is facing during the construction.
\end{abstract}

Keywords: Small and medium-sized cities, Urbanization, Strategy choice.

\section{Introduction}

China's large-scale urbanization over past three decades has been unprecedented in human history. Nearly half a billion people have moved into cities, adding to a total of 700 million urban residents. In 1949, only around 11 percent of Chinese lived in cities (National Bureau of Statistics of China, 2013). By the end of 2012, the proportion of China's urban population had exceeded 52.57 percent (National Bureau of Statistics of China, 2013). From 1980 to 2010, China's share of the world's total urban residents grew from 10 percent to nearly 19 percent. In the next 20 years, about 310 million additional Chinese people are expected to move to cities (Population Division of the United Nations Department of Economic and Social Affairs, 2011).

From 1949 to 2012, China's urbanization evolved through six stages with varying rates of change (see table 1.1). Since 1996, China's urbanization has entered a rapid development period. Annual average growth of urbanization rate increased over 1 percent point. During this period, ongoing reforms and strong industrial demand have become the two major driving forces (United Nations Development Program, 2013).

Table1.1 Comparison of China's urbanization Speed in Different Period

\begin{tabular}{cccc}
\hline Period & Year & $\begin{array}{c}\text { Annual average growth of urban } \\
\text { population (millions of people) }\end{array}$ & $\begin{array}{c}\text { Annual average growth of urbanization } \\
\text { rate (percentage point) }\end{array}$ \\
\hline 6the Five-Year Plan Period & $1981-1985$ & 11.91 & 0.86 \\
7the Five-Year Plan Period & $1986-1990$ & 10.20 & 0.54 \\
8the Five-Year Plan Period & $1991-1995$ & 9.96 & 0.53 \\
9the Five-Year Plan Period & $1996-2000$ & 21.46 & 1.44 \\
10the Five-Year Plan Period & $2001-2005$ & 20.61 & 1.35 \\
11the Five-Year Plan Period & $2006-2010$ & 21.53 & 1.39 \\
12the Five-Year Plan Period & $2010-2012$ & 21.02 & 1.33 \\
\hline
\end{tabular}

Note: "China Statistical Year book 2012"

The standards of urban classification are made by scale. According to Circular of the State Council, all cities can be classified into five groups: small cities (with populations of less than half a million residents), medium-sized cities (with populations from half a million to a million), large cities (with populations from a million to five million), megacity (with populations from five million to ten million) and super city (with populations over ten million). Small and 
medium-sized city is a strategic pitch in China's administrative division system. The healthy development of small and medium-sized cities is of decisive significance for realizing integration urban and rural area, improving the demand structure, building a moderately prosperous society and speeding up socialist modernization.

By the end of 2012, all these regions influenced by small and medium-sized cities directly or indirectly have reached 93.4 million square kilometers, accounting for 97.3 percent; the population reached 1.156 billion, accounting for 85.4 percent of total population. In 2012, economic gross of these regions amounts to 43.92 trillion yuan, accounting for 84.5 percent of the total national economy; fiscal revenue of local governments reached 4252.18 billion yuan, accounting for 69.62 percent of the local finance income. So the healthy development of small and medium-sized cities are helpful for the overall development, playing an important role in the healthy development of the whole city. Small and medium-sized city is the main battlefield of new urbanization construction.

\section{Characteristics of Small and Medium-Sized Cities Urbanization}

\subsection{The Level of Development is Uneven, Significant Regional Differences}

Task group of scientific evaluation system for the development of small and medium-sized cities in 2014 research suggests that the top 10 cities all located in the eastern region was evaluated by scientific development index, abstemious city index, potential investment index and regional power index. From the regional distribution point of view of the eastern region 59 finalists (see table 2.1). Different regions have different levels of economic development and urbanization development as well.

Stable 2.1 National Comprehensive Strength Hundred Counties ( cities ) in 2013

\begin{tabular}{|c|c|c|c|c|c|c|c|}
\hline Sort & City & Sort & City & Sort & City & Sort & City \\
\hline 1 & Kunshan in Jiangsu & 26 & $\begin{array}{l}\text { Yangzhong in } \\
\text { Jiangsu }\end{array}$ & 51 & Renqiu in Hebei & 76 & Yizheng in Jiangsu \\
\hline 2 & Jiangyin in Jiangsu & 27 & Haining in Zhejiang & 52 & Longhai in Fujian & 77 & Feixi in Anhui \\
\hline 3 & $\begin{array}{c}\text { Zhangjiagang in } \\
\text { Jiangsu }\end{array}$ & 28 & $\begin{array}{l}\text { Shouguang in } \\
\text { Shandong }\end{array}$ & 53 & Dafeng in Jiangsu & 78 & $\begin{array}{l}\text { Pingyang in } \\
\text { Zhejiang }\end{array}$ \\
\hline 4 & Taicang in Jiangsu & 29 & $\begin{array}{l}\text { Tengzhou in } \\
\text { Shandogn }\end{array}$ & 54 & Xiaoyi in Shanxi & 79 & Guixi in Jiangxi \\
\hline 5 & Cixi in Zhejiang & 30 & Yuluan in Zhejiang & 55 & Yuzhou in Henan & 80 & Dangtu in Anhui \\
\hline 6 & Yixing in Jiangsu & 31 & Fuqing in Fujian & 56 & Pizhou in Jiangsu & 81 & $\begin{array}{l}\text { Chiping in } \\
\text { Shandogn }\end{array}$ \\
\hline 7 & Jinjiang in Fujian & 32 & $\begin{array}{l}\text { Zhuanghe in } \\
\text { Liaoning }\end{array}$ & 57 & Anda in Heilongjiang & 82 & $\begin{array}{l}\text { Guangfeng in } \\
\text { Jiangxi }\end{array}$ \\
\hline 8 & Changsha in Hunan & 33 & Hai'an in Jiangsu & 58 & Korla in Xinjiang & 83 & $\begin{array}{l}\text { Inner Mongolia } \\
\text { Huolinguole }\end{array}$ \\
\hline 9 & $\begin{array}{l}\text { Shuangliu in } \\
\text { Sichuan }\end{array}$ & 34 & Nan'an in Fujian & 59 & $\begin{array}{l}\text { Tuoketuo Power Plant } \\
\text { in Inner Mogolia }\end{array}$ & 84 & Wuqi in Shanxi \\
\hline 10 & $\begin{array}{l}\text { Haicheng in } \\
\text { Liaoning }\end{array}$ & 35 & Laixi in Shandong & 60 & Nanchang in Jiangxi & 85 & Feidong in Anhui \\
\hline 11 & Yiwu in Zhejiang & 36 & Hui'an in Fujian & 61 & Kaiyuan in Liaoning & 86 & Ganyu in Jiangxi \\
\hline 12 & Yutao in Zhejiang & 37 & $\begin{array}{l}\text { Laizhou in } \\
\text { Shandong }\end{array}$ & 62 & Xingyang in Henan & 87 & Peixian in Jiangsu \\
\hline 13 & $\begin{array}{l}\text { Zengcheng in } \\
\text { Guangdong }\end{array}$ & 38 & $\begin{array}{l}\text { Zhaodong in } \\
\text { Heilongjiang }\end{array}$ & 63 & Jurong in Jiangsu & 88 & Anning in Yunnan \\
\hline 14 & $\begin{array}{l}\text { Longkou in } \\
\text { Shandong }\end{array}$ & 39 & $\begin{array}{l}\text { Zhaoyuan in } \\
\text { Shangdong }\end{array}$ & 64 & Qianguo in Jilin & 89 & $\begin{array}{l}\text { Changyi in } \\
\text { Shandong }\end{array}$ \\
\hline 15 & $\begin{array}{l}\text { Jungar banner in } \\
\text { Inner Mongolia }\end{array}$ & 40 & Rugao in Jiangsu & 65 & Donggang in Liaoning & 90 & $\begin{array}{l}\text { Huantai in } \\
\text { Shandong }\end{array}$ \\
\hline 16 & $\begin{array}{l}\text { Rongcheng in } \\
\text { Shandong }\end{array}$ & 41 & Xintai in Shangdong & 66 & Yongkang in Zhejiang & 91 & $\begin{array}{l}\text { Rushan in } \\
\text { Shandong }\end{array}$ \\
\hline 17 & $\begin{array}{l}\text { Zouping in } \\
\text { Shandong }\end{array}$ & 42 & Deqing in Zhejiang & 67 & Xinghua in Jiangsu & 92 & $\begin{array}{l}\text { Qingzhou in } \\
\text { Shandong }\end{array}$ \\
\hline 18 & Zhuji in Zhejiang & 43 & Wenling in Zhejiang & 68 & Yanji in Jilin & 93 & $\begin{array}{l}\text { Liaozhong in } \\
\text { Liaoning }\end{array}$ \\
\hline 19 & Qian'an in Hebei & 44 & Qidong in Jiangsu & 69 & Penglai in Shandong & 94 & Jingbian in Shanxi \\
\hline 20 & $\begin{array}{l}\text { Wafangdian in } \\
\text { Liaoning }\end{array}$ & 45 & $\begin{array}{l}\text { Changxing in } \\
\text { Zhejiang }\end{array}$ & 70 & Gaoyao in Guangdong & 95 & Pingguo in Guangxi \\
\hline
\end{tabular}




\begin{tabular}{|c|c|c|c|c|c|c|c|}
\hline 21 & Shishi in Fujian & 46 & Pixian in Sichuang & 71 & Gaoping in Shanxi & 96 & Liling in Hunan \\
\hline 22 & Yueqing in Zhejiang & 47 & Yima in Henan & 72 & Gaoyou in Jiangsu & 97 & Lingwu in Ningxia \\
\hline 23 & Danyang in Zhejiang & 48 & $\begin{array}{l}\text { Fengcheng in } \\
\text { Shandong }\end{array}$ & 73 & Fugu in Shanxi & 98 & Golmud in Qinghai \\
\hline 24 & Fuyang in Zhejiang & 49 & Xinzheng in Henan & 74 & Ningguo in Anhui & 99 & Panxian in Guizhou \\
\hline 25 & Ruian in Zhejiang & 50 & $\begin{array}{c}\text { Dashiqiao in } \\
\text { Liaoning }\end{array}$ & 75 & Anxi in Fujian & 100 & Daye in Hubei \\
\hline
\end{tabular}

Note: Green Book of Small and Medium-sized Cities (2013)

\subsection{The Spatial Distribution of General Equilibrium, And the Development of Relatively Stable}

In each province or autonomous region, small and medium-sized cities play very important roles and its distribution is relatively uniform. From 2004 to 2012, although the number of small and medium-sized cities decreased somehow, the average population size of small and medium-sized cities increased from 542.83 million to 711.82 million, the proportion of urban residents in small and medium-sized cities increased from 41.46 percent to 52.57 percent (see table 2.2). From the overall point of view, the development of small and medium-sized cities in China is relatively stable, non-agriculture population keeps increasing steadily.

Table 2.2 Small and Medium-Sized Cities Non-Agricultural Population in China, 2001-2012

\begin{tabular}{|c|c|c|c|c|}
\hline \multirow[b]{2}{*}{ Year } & \multicolumn{2}{|c|}{ Quantity } & \multicolumn{2}{|c|}{ Population } \\
\hline & Small cities & Medium-sized cities & $\begin{array}{l}\text { Non-agricultural Population } \\
\text { (millions) }\end{array}$ & Percent $(\%)$ \\
\hline 2004 & 67 & 111 & 542.83 & 41.46 \\
\hline 2005 & 65 & 108 & 562.12 & 42.99 \\
\hline 2006 & 63 & 106 & 582.88 & 44.34 \\
\hline 2007 & 58 & 111 & 606.33 & 45.89 \\
\hline 2008 & 55 & 110 & 624.03 & 46.99 \\
\hline 2009 & 53 & 110 & 645.12 & 48.34 \\
\hline 2010 & 53 & 109 & 669.28 & 49.95 \\
\hline 2011 & 53 & 108 & 690.79 & 51.27 \\
\hline 2012 & 54 & 108 & 711.82 & 52.57 \\
\hline
\end{tabular}

Note: "China Statistical Year Book" 2005 to 2012

\subsection{The Extensive Mode of Economic Development Quality of Urbanization, The poor}

According to the statistics of "The State of China's Cities (2012/2013)" shows that China's urban system operates in a strict administrative hierarchy which administrative power still plays a significant role in the mid-west regions. Due to lack of market competition, concept of sustainable development, system innovation and technical innovation are relatively backward in these cities. Rapid economic development and rise relies on high input, high consumption of energy resources, even spoiling ecological environment.

So the trend of general environmental deterioration in China hasn't been fundamentally controlled and environmental conflicts are increasing in intensity. In some key basins and coastal areas, for instance, water pollution is so severe, as is the phenomenon of cloudy brownish haze in some regions and cities, and the emission of major pollutants exceeds the environmental capacity in many regions. According to the monitoring results of the Ministry of Environmental Protection on air quality of most cities in China from 2005 to 2010, the proportion of cities with air quality equal to or above Grade I standard decreased from 4.2 percent to 3.6 percent; the proportion of cities with air quality equal to or above Grade II standard increased significantly from 56.1 percent to 79.2 percent; and the proportion of cities with air quality equal to or below Grade III standard has decreased from 39.7 percent to 17.2 percent. The tendencies displayed were that the proportion of cities with air quality equal to or above Grade II standard increased, while the proportion of cities with air quality equal to or above Grade I standard and equal to or below Grade III standard decreased (The State of China, 2012).

\section{Policy Options for the Healthy Development of Small and Medium-Sized Cities Urbanization}

"City Development Research Group Research Report (2011)" put forward that speeding up urbanization is an important content of China's "economic restructuring", is the current urgent task of economic development. The key to urbanization is the development of small and medium-sized city development. It is important for China to develop small and medium-sized city in the coming years.

China's urbanization counts as the biggest and fastest social movement in human history, which has turned Chinese society on its head and raises many difficult questions for policy makers. The region diffidence of 
urbanization development is remarkable, and always expanding, different of cities and different development stage have its own distinct characteristics and different demands, so that urbanization should take diversified way to suit local conditions and put forward the healthy sustainable urbanization strategy to suit their individual need, which is the key of China's urbanization in China.

\subsection{Understand the Connotation of the Development, Pay Attention to the Quality of Urbanization}

Urbanization is a dynamic and complex process of comprehensive development, urbanization is not only the physical expansion of cities and the growth of population living in them, but also is a change of social production and life-style greatly. Urbanization should not only pay attention to the development of the economy, but also strengthen institutions and governance, including in key areas such as population administration, land management, finance and taxation, urban housing systems, public administration and environmental management. Urbanization can't strive merely for quantity of city, and should place greater emphasis on improving the quality of city to promote the development of long-term. The resources consumed in intensive growth pattern are obviously lower than in extensive growth pattern. Intensive urbanization development pattern is the trend of future development of small and medium-sized city.

\subsection{Optimize the Industrial Structure, Promote the Sustainable Development}

Industrial development is power and source of development rule of law urbanization development, is the city of radiation source of driving force. Throughout the history of world urbanization, each of great advances issued from industrial development. Urbanization must realize an industry to upgrade with transition, optimize and upgrade the industrial structure and balance the structures of primary, secondary and tertiary industries development. Relying on technological innovation and scientific management, constructing city's strategic industrial structure can promote the city sustainable development.

\subsection{Regulate Government Management, Perfect the Management Mechanism}

China's urbanization is closely linked to the governmental system or the state, including governments at all levels and spatial scales, and still runs key sectors of the economy directly and the rest indirectly. Not only is the state omnipotent in the major sectors of the economy, it also manages society directly in many ways. Thus, inevitably, the government plays an important part in the urbanization process and the development of the urban system. The process of urbanization of the small and medium-sized cities will be impossible without government. Government should make scientific plans for the scale and layout of urban agglomerations; and make small and medium-sized cities better in order to develop industries, provide public services, create jobs, and attract population. To reach the goal of enhancing ability of management city, continuously promote overall reform in public utilities. We should separate government administration from the management of enterprises, state assets, public institutions, and social organizations, and build a well-structured, clean and efficient service-oriented government that has scientifically defined functions and satisfies the people.

\section{Results}

Reviewing the course of world urbanization, we can find that the roads each country took are diverse and plenty. In Britain, urbanization was promoted by industrialization. Newtown construction is a key way for the urbanized advancement in South Korea. German vocational education pattern has played an important role in promoting urbanization. Although these successful experiences are well worth absorbing and learning, it doesn't mean that we can accept hastily and without thinking it seriously. We should choose a right path of urbanization, which combined with China's conditions. For small and medium-sized city, we should transform the development pattern, stress the active function of people, and balance the fairness and efficiency, focusing on improving the quality of development. To improve the quality of urbanization, flexible and pertinent measures should be adopted in the light of different characteristics and steps of cities.

\section{References}

National Bureau of Statistics of China. (2013). China Statistical Yearbook 2012. Beijing: China Statistics Press.

National Bureau of Statistics of China. (2013). Statistical Communiqué of the People's Republic of China on the National Economic and Social Development in 2012.

http://news.xinhuanet.com/politics/2013-02/3/c_114772758.htm

Population Division of the United Nations Department of Economic and Social Affairs. (2011). World Population Prospects: The 2010 Revision and World Urbanization Prospects. New York: United Nations.

United Nations Development Program. (2013). China Human Development Report (2013): Sustainable and Liveable Cities: Toward Ecological Urbanization. Beijing: China Translation and Publishing Corporation.

\section{$(\mathrm{cc}) \mathrm{Br}$}

This work is licensed under a Creative Commons Attribution 3.0 License. 